\title{
Relative preference and demographic parameters of Encarsia formosa Gahan against Trialeurodes vaporariorum (Westwood)
}

\author{
Anamika Walia, S. C. Verma, P. L. Sharma, Nidhi Sharma and Shivani Palial ${ }^{*}$ (i)
}

\begin{abstract}
Background: The greenhouse whitefly, Trialeurodes vaporariorum (Westwood) (Hemiptera: Aleyrodidae), is a cosmopolitan, polyphagous and a serious pest of vegetables and ornamentals in greenhouse. Encarsia formosa Gahan (Hymenoptera: Aphelinidae) is an important primary endoparasitoid species of the greenhouse whitefly.

Results: In the present study, per cent parasitisation attained 50\% on the 4th instar and $46 \%$ on the third 3 rd instar of $T$. vaporariorum by E. formosa. The mean duration period of the parasitoid from egg to host mummification, mummification to adult emergence (pupal period) was 11 and 7.8 days on 3rd instar and 8.5 and 7.6 days on 4th instar, respectively. The total time period from egg to adult emergence reached 18.8 days on 3rd instar and 16.2 days on 4th instar. Longevity of the female parasitoids was 8.3 and 8.8 days on 3rd and 4th instars, respectively. The pre-ovipositional, ovipositional and post-ovipositional periods of the parasitoid were 1.2, 6.4 and 1.0 days on 3rd instar and 1.2, 6.7 and 1.0 days on 4th instar, respectively. The finite rate of natural increase $(\lambda)$, doubling time and weekly multiplication rate of the 3 rd instar was $1.16 \pm 0.002$ times per day, $4.71 \pm 0.04$ days and $2.80 \pm 0.03$ folds, respectively and $1.17 \pm 0.002$ times per day, $4.34 \pm 0.04$ days and $3.06 \pm 0.03$ folds for the 4 th instar.

Conclusions: Studies indicated that the 4 th nymphal instar of the host was more suitable for parasitisation with $E$. formosa. The parasitoid species could be mass multiplied and utilised as a component of integrated pest management programme of T. vaporariorum after evaluation under field conditions.
\end{abstract}

Keywords: Trialeurodes vaporariorum, Encarsia formosa, Biology, Relative preference

\section{Background}

The greenhouse whitefly, Trialeurodes vaporariorum Westwood (Hemiptera: Aleyrodidae), a cosmopolitan polyphagous species is found in greenhouses as a serious pest of vegetables and ornamentals (Singh and Sood 2018). Under protected environment, greenhouse whitefly can complete 13 generations in a year. In addition, it transmits many viral pathogens and produces honeydew for sooty moulds to grow and reduced crop yield (Kos et al. 2009). It is also a vector of the broad mite, Polyphagotarsonemus

\footnotetext{
* Correspondence: spalial33@gmail.com

Dr. YS Parmar University of Horticulture and Forestry, Nauni, Solan, Himachal Pradesh, India
}

\section{Springer Open}

latus Banks, another serious pest of several greenhouse crops (Palevsky et al. 2001). In India, the pest was recorded for the first time in Nilgiri hills of Tamil Nadu on potato (David 1971) and subsequently, it has been reported to infest 102 host plants belonging to 36 plant families (Sood and David 2012). In Himachal Pradesh, Sood and Sood (2002) recorded this whitefly on 44 plant species which comprised of ornamentals (29 species), vegetable crops (6 species), field crops ( 2 species), medicinal plants ( 3 species) and weed hosts (4 species).

For the control of $T$. vaporariorum, farmers mainly use synthetic insecticides which result in problems of insecticide resistance, pest resurgence, secondary pest (c) The Author(s). 2021 Open Access This article is licensed under a Creative Commons Attribution 4.0 International License, which permits use, sharing, adaptation, distribution and reproduction in any medium or format, as long as you give appropriate credit to the original author(s) and the source, provide a link to the Creative Commons licence, and indicate if changes were made. The images or other third party material in this article are included in the article's Creative Commons licence, unless indicated otherwise in a credit line to the material. If material is not included in the article's Creative Commons icence and your intended use is not permitted by statutory regulation or exceeds the permitted use, you will need to obtain permission directly from the copyright holder. To view a copy of this licence, visit http://creativecommons.org/licenses/by/4.0/. 
outbreak, pesticide residues and negative impact on environment and non-target organisms (Singh 2017). One of the most popular and important biological control agents for the control of the greenhouse whitefly in protected cultivation is the parasitic wasp, Encarsia formosa Gahan (Hymenoptera: Aphelinidae). The parasitic wasp has been used for many years for biological control of $T$. vaporariorum and it is one of the most successful biological agents in greenhouse crops around the world. E. formosa is uniparental, its females are primary endoparasitoids of the greenhouse whitefly (Hoddle et al. 1998a). The parasitoid females oviposit in all immature stages of $T$. vaporariorum, except the egg and mobile first instar, but the 3rd and 4th nymphal instars are the most suitable stages for parasitisation. Emergence of the parasitoid is highest from these stages (Soto et al. 2001). Encarsia feeds on honeydew and on the body fluid of 1st and 2nd instar of the whitefly (Boisclair et al. 1990). Singh and Sood (2018) reported 93.6\% parasitisation of $T$. vaporariorum by E. formosa in Kangra district of Himachal Pradesh. Although the occurrence of $E$. formosa has been reported in India, its biocontrol potential has not been studied so far. Therefore, the work aimed to study the biology and population growth parameters of $E$. formosa when parasitising nymphs of $T$. vaporariorum.

\section{Methods}

\section{Rearing of $T$. vaporariorum}

The stock culture of the greenhouse whitefly was maintained in the biocontrol laboratory by collecting infested leaves of French bean in the field at Entomology Research Farm of Dr. YS Parmar University of Horticulture and Forestry, Nauni, Solan (HP) India $\left(30.85^{\circ} ; 77.16^{\circ}\right.$ E). Adults of whitefly were released on potted French bean plants in insect rearing cages $(45 \times 45 \times 45 \mathrm{~cm})$. The newly emerged adults were shifted to insect rearing cages and were provided by French bean plants for oviposition. After 2 days of exposure, the plants with eggs of T. vaporariorum were shifted to another cage and observed for egg hatching. The young emerged nymphs were used for further rearing on French bean plants. The greenhouse whitefly was reared and multiplied for 2 generations before utilising for experiments.

\section{Rearing of the parasitoid, E. formosa}

Initial culture of the $E$. formosa was procured from the Department of Entomology at CSK Himachal Pradesh Krishi Vishvavidyalaya, Palampur (HP) India. A pure culture of $E$. formosa was maintained on the nymphs of greenhouse whitefly on French bean plants grown in the experimental farms and polyhouses of the Department of Entomology, Dr YS Parmar University of Horticulture and Forestry, Nauni, Solan. The emerged adults of $E$. formosa were carefully transferred to glass tubes and provided with a fine streak of honey solution as food. Then the $T$. vaporariorum nymphal colonies were offered to parasitoids for multiplication. After $24 \mathrm{~h}$, new batches of nymphs were provided to the parasitoid and process was repeated till all the parasitoids died. The food of the parasitoid was changed daily. The parasitoid was reared and multiplied for one generation before using in the experiments.

\section{Relative preference of $E$. formosa to different nymphal instars of $T$. vaporariorum}

The newly emerged adults of $E$. formosa were offered with each nymphal instar of $T$. vaporariorum simultaneously. In the experiment, each female of E. formosa was provided by 10 individuals of 1 st, 2nd, 3rd and 4th nymphal instars of $T$. vaporariorum separately on a French bean leaves simultaneously in a clip cage. Each treatment was replicated 5 times. After $24 \mathrm{~h}$, the parasitised nymphs were removed and each instar was placed separately and observed daily for emergence of adults. Data collected were converted to percent parasitism for different instars.

\section{Developmental time}

Biology of E. formosa was studied on 3rd and 4th instar nymphs of the greenhouse whitefly. Ten nymphs of 3rd or 4th of the whitefly infesting French bean leaves were exposed to a single female parasitoid held in a clip cage. Clip cages with parasitoids were removed after $24 \mathrm{~h}$ and observed under a microscope to segregate the parasitised nymphs from the host-fed and healthy ones. The shrinked and mutilated nymphs were considered as host-fed and remaining ones as healthy. Data on the duration of egg to mummification, mummification to adult emergence, adult longevity, fecundity and sex ratio were recorded.

Parasitism and population growth parameters of $E$. formosa Population growth parameters of E. formosa were studied on 3rd and 4th nymphal instars of $T$. vaporariorum by constructing fertility life tables separately. For this purpose, 10 nymphs of each instar were exposed to a colony of E. formosa for parasitism for $24 \mathrm{~h}$. Each set was replicated 10 times. After $24 \mathrm{~h}$, the parasitised nymphs were used for further rearing of the parasitoid. Adults emerged from these parasitised nymphs were offered 10 host nymphs for parasitism and fed for $24 \mathrm{~h}$. After $24 \mathrm{~h}$, the old batch of nymphs was replaced by a new one and the process continued until all the parasitoids died.

Data on age-specific survival, fecundity (parasitised nymphs) and daily host feeding were recorded. Total host killing was calculated by adding the number of hosts parasitised and the number of hosts fed. Population growth parameters of the parasitoid were calculated 
by constructing fertility tables as per formulae given by Birch (1948), elaborated by Howe (1953) and Carey (1993) by using various variables: such as age of individuals in days (pivotal age, $X$ ), $l_{x}$ proportion of individuals still alive at age $X$ (survival value, $l_{x}$ ), number of female off-springs produced (calculated on the basis of sex ratio) per female in the age interval $X$ (fecundity rate, $m_{x}$ ). Using abovementioned variables, different population growth parameters were evaluated to find out the anticipated rate of multiplication of the parasitoid after each generation and suitable host stage for parasitisation.

The theoretically population growth parameters were calculated using the following equations:

(1) Gross reproductive rate (GRR): It is the total number of female eggs laid per female and calculated as:

$\mathrm{GRR}=\Sigma \mathrm{m}_{\mathrm{x}}$

(2) Net reproductive rate $\left(R_{o}\right)$ : It is the rate of multiplication of the population in each generation and measured in terms of females produced per generation. It was calculated as:

$\mathrm{R}_{0}=\Sigma \mathrm{l}_{\mathrm{x}} \mathrm{m}_{\mathrm{x}}$

(3) Approximate generation time $\left(T_{\mathrm{c}}\right)$ : It is the mean length of the generation (birth to weighed mean reproductive age of adult) and was calculated by the formula:

$\mathrm{T}_{\mathrm{c}}=\Sigma \mathrm{xl}_{\mathrm{x}} \mathrm{m}_{\mathrm{x}}$

(4) Innate capacity for natural increase $\left(r_{\mathrm{c}}\right)$ : It is the capacity of a species to increase in number (the reproductive rate) and calculated by the formula:

$r_{c}=\log _{e} R_{o} / T_{c}$

(5) True intrinsic rate of increase $\left(r_{\mathrm{m}}\right)$ : It is the actual rate of increase of a population under specified environmental conditions in which space and food are unlimited. It was calculated by solving the equation,

$\sum \mathrm{e}^{-\mathrm{rmx}} \mathrm{l}_{\mathrm{x}} \mathrm{m}_{\mathrm{x}}=1$ by iteration method using Excel program.

(6) True generation time (T): It is the mean period elapsing from the birth of parents to the birth of off-springs. It was calculated by the formula:

$\mathrm{T}=\log _{\mathrm{e}} \mathrm{R}_{\mathrm{o}} / \mathrm{r}_{\mathrm{m}}$

(7) Finite rate of natural increase $(\lambda)$ : It is the number of times the population increases per unit time. The value was calculated by the formula:

$$
\lambda=\operatorname{antilog}_{\mathrm{e}} \mathrm{r}_{\mathrm{m}}
$$

(8) Doubling time (DT): It is the time taken by a species to double its population and was calculated by the formula:

$$
\mathrm{DT}=\log _{\mathrm{e}} 2 / \mathrm{r}_{\mathrm{m}}
$$

(9) Weekly multiplication rate (WM): It is the number of times the population multiplies in a week and was calculated by the formula:

$$
\mathrm{WM}=\mathrm{e}^{7 \mathrm{rm}}
$$

\section{Data analysis}

Data was analysed by using one way analysis of variance (ANOVA) with a completely randomised design after appropriate transformation through the online OP-STAT software (Sheoran et al. 1998). The means that differed significantly were separated by least significant difference (LSD) at $p=0.05$. Data on the percentage of parasitism, host feeding and host killing were subjected to normality test before ANOVA. The value of $\mathrm{K}-\mathrm{S}$ test statistic $(D) \leq 0.25385$ and $p \geq 0.127$ indicate that the data is normally distributed.

\section{Results}

Relative preference of $E$. formosa to different nymphal stages of $T$. vaporariorum

The relative preference of $E$. formosa to different (first, second, third and fourth) nymphal stages of $T$. vaporariorum was determined by offering 10 nymphs of each instar on French bean leaves for $24 \mathrm{~h}$ in 5 replications. Encarsia sp. is koinobiont in nature, so the development of the whitefly nymphs continued after parasitism. The parasitoid showed 2 pest-killing behaviours, viz. parasitism and host feeding. Host feeding and parasitism by the parasitoid was observed in all the 4 nymphal instars of the whitefly, and parasitisation was not noticed in hosts used for feeding. Significant differences were recorded in the parasitism $(F=39.64 ; \mathrm{df}=3,16 ; p<0.001)$, hostfeeding $(F=31.04 ; \mathrm{df}=3,16 ; p<0.001)$ and total host killing $(F=16.47 ; \mathrm{df}=3,16 ; p<0.001)$ rates of $E$. formosa to different nymphal instars of $T$. vaporariorum. Percent parasitisation recorded on 4th instar (50\%) and (46\%) on 3rd instar of $T$. vaporariorum by E. formosa was statistically at par with each other. The parasitoid, E. formosa, parasitised $16 \%$ nymphs of the 2nd instar which differed statistically than the 1 st nymphal instar (6\%) of T. vaporariorum. On an average, $28 \%$ host feeding was recorded on the 1st instar, followed by 2nd (12\%) and 3rd instars (4\%), whereas there was $2 \%$ host killed in 4 th instar. The parasitoid preferred younger nymphs for host feeding and older ones for parasitism. After pooling, the total 
host killing (parasitisation and host feeding) by the parasitoid was $52 \%$ of 4 th nymphal instars were statistically at par with 3rd instar (50\%) nymphs. The parasitoid killed 34 and $28 \%$ of the 1st and 2nd nymphal instars of the greenhouse whitefly, respectively. The relative proportion of parasitism and host feeding by the parasitoid was 0.17 and 0.83 on 1 st instar, 0.57 and 0.43 on 2 nd instar, 0.91 and 0.06 on 3rd instar and 0.97 and 0.03 on 4th instar, respectively (Table 1 ).

\section{Developmental time}

\section{Third instar of T. vaporariorum}

The mean duration of the parasitoid from egg to host mummification was 11 days, whilst from mummification to adult emergence (pupal period) was 7.8 days (Table 2). The total period from egg to adult emergence was 18.8 days. The longevity of the female parasitoids was 8.3 days. The pre-ovipositional, ovipositional and post-ovipositional periods of the parasitoid attained 1.2, 6.4 and 1.0 days, respectively.

\section{Fourth instar of $T$.vaporariorum}

The mean duration from egg to host mummification was 8.5 days. The pupal development from mummification to adult emergence was completed in 7.6 days. The total duration from egg to adult emergence was 16.2 days (Table 2 ). The female longevity was 8.8 days, which comprised of pre-ovipositional, ovipositional and post-ovipositional periods of $1.2,6.7$ and 1.0 days, respectively.

\section{Parasitism and population growth parameter}

The population growth parameters of $E$. formosa on $T$. vaporariorum were determined by raising fertility tables (Figs. 1 and 2). The data on age-specific survival and fecundity of the parasitoid were accumulated to develop the fertility tables and to determine the population growth parameters.

\section{Third instar of T. vaporariorum}

E. formosa showed $87 \%$ survival until adult emergence after parasitisation on the 3rd instar nymphs of $T$. vaporariorum at the pivotal age of 18 days. The adult mortality started on the 6th day of oviposition. Thereafter, a gradual decrease in the survival rate of the parasitoid was observed and on 30th day of the pivotal age, all the parasitoids died. The parasitoid started laying eggs at the pivotal age of 19 days and on an average 1 female egg/female was laid on that day (Fig. 1). The age-specific fecundity increased gradually and was maximum (5.79 female/female) on 22nd day of the pivotal age, which thereafter declined and was minimum ( 0.11 female/female) on the 28 th day of the pivotal age. Population growth parameters obtained from the data on the age-specific survival and fecundity, presented in Table 3 showed that the gross reproductive rate (GRR) and net reproductive rate $\left(R_{0}\right)$ was $27.78 \pm 0.33$ and $26.71 \pm 0.56$ females/female, respectively. The approximate generation time $\left(T_{\mathrm{c}}\right)$ and the true generation time $(T)$ were $22.53 \pm 0.26$ and $22.32 \pm 0.25$ days, respectively. The parasitoid had innate capacity for natural increase $\left(r_{\mathrm{c}}\right)$ of $0.1458 \pm 0.001$ and true intrinsic rate of increase $\left(r_{\mathrm{m}}\right)$ was $0.1472 \pm 0.001 \mathrm{females} /$ female/day. The finite rate of natural increase $(\lambda)$ was estimated as $1.16 \pm 0.002$ times per day. The parasitoid had the capacity to double its population in $4.71 \pm 0.04$ days with a weekly multiplication rate of $2.80 \pm 0.03$ folds.

\section{Fourth instar of $T$. vaporariorum}

The parasitoid, E. formosa when reared on the 4th instar of T. vaporariorum, showed $88 \%$ survival up to adult emergence, at the pivotal age of 16 days (Fig. 2). Further mortality started on the 6th day of oviposition. Thereafter, a gradual decrease in the survival rate of the parasitoid was observed and on 29th day of the pivotal age, all the parasitoids died. The parasitoid started laying eggs at the pivotal age of 17 days and on an average 0.13 female eggs/female was laid on that day. The agespecific fecundity increased gradually and was maximum (6.59 female/female) on 21st day of the pivotal age, which thereafter decreased to the minimum (0.4 female/ female) on the 26th day of the pivotal age. Population growth parameters obtained from the data on the agespecific survival and fecundity of parasitoids showed that the gross reproductive rate (GRR) and net reproductive rate $\left(R_{0}\right)$ was $29.93 \pm 0.43$ and $27.15 \pm 0.57$ female progeny/female, respectively. The approximate generation

Table 1 Relative preference by E. formosa to different nymphal instars of T. vaporariorum

\begin{tabular}{llllll}
\hline Instar & $\begin{array}{l}\text { Parasitism } \\
\text { (\%) }\end{array}$ & $\begin{array}{l}\text { Host } \\
\text { feeding (\%) }\end{array}$ & $\begin{array}{l}\text { Total host } \\
\text { killing (\%) }\end{array}$ & \multicolumn{2}{l}{$\begin{array}{l}\text { Relative proportion } \\
\text { Parasitism }\end{array}$} \\
\hline I & $6.00 \pm 2.45 \mathrm{a}$ & $28.00 \pm 20 \mathrm{a}$ & $34.00 \pm 2.45 \mathrm{a}$ & $0.17 \pm 0.07$ & $0.83 \pm 0.07$ \\
II & $16.00 \pm 2.45 \mathrm{a}$ & $12.00 \pm 20 \mathrm{~b}$ & $28.00 \pm 2.00 \mathrm{a}$ & $0.57 \pm 0.07$ & $0.43 \pm 0.07$ \\
III & $46.00 \pm 5.10 \mathrm{~b}$ & $4.00 \pm 2.45 \mathrm{bc}$ & $50.00 \pm 3.16 \mathrm{~b}$ & $0.91 \pm 0.06$ & $0.09 \pm 0.06$ \\
IV & $50.00 \pm 3.16 \mathrm{c}$ & $2.00 \pm 2.00 \mathrm{~cd}$ & $52.00 \pm 3.74 \mathrm{c}$ & $0.97 \pm 0.03$ & $0.03 \pm 0.03$ \\
$C D(p=0.05)$ & $(9.14)$ & $(9.37)$ & $(5.22)$ & & \\
\hline
\end{tabular}

Means within a column followed by same alphabet are not significantly different at $p \leq 0.05$ (LSD test) 
Table 2 Biological parameters of E. formosa on third and fourth instars of T. vaporariorum

\begin{tabular}{llllll}
\hline Parameter & Third instar & & & \multicolumn{2}{l}{ Fourth instar } \\
\cline { 2 - 3 } \cline { 5 - 6 } & Estimate \pm SE & Range (days) & & Estimate \pm SE & Range (days) \\
\hline Oviposition to mummification period (days) & $11 \pm 0.15$ & $10-12$ & $8.5 \pm 0.17$ & $8-9$ \\
Mummification to adult emergence period (days) & $7.8 \pm 0.18$ & $7-9$ & $18.6 \pm 0.16$ & $7-9$ \\
Total developmental period (days) & $18.8 \pm 0.2$ & $8.3 \pm 0.15$ & $5-10$ & $16.2 \pm 0.20$ & $15-18$ \\
Adult longevity (days) & $1.2 \pm 0.07$ & $1-2$ & $8.8 \pm 0.19$ & $6-10$ \\
Pre-oviposition period (days) & $6.4 \pm 0.12$ & $4-7$ & $1.2 \pm 0.07$ & $1-2$ \\
Oviposition period (days) & $1.0 \pm 0.0$ & 1 & $6.7 \pm 0.09$ & $5-8$ \\
Post-oviposition period (days) & & & $1.0 \pm 0.0$ & 1
\end{tabular}

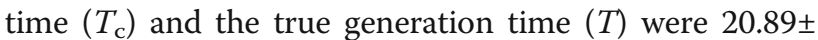
0.28 and $20.69 \pm 0.27$ days, respectively (Table 3 ). The parasitoid had innated capacity for natural increase $\left(r_{\mathrm{c}}\right)$ of $0.1581 \pm 0.002$ and true intrinsic rate of increase $\left(r_{\mathrm{m}}\right)$ was $0.1596 \pm 0.002$ females/female/day. The finite rate of natural increase $(\lambda)$ was estimated as $1.17 \pm 0.002$ times per day. The parasitoid had the capacity to double its population in $4.34 \pm 0.04$ days with a weekly multiplication rate of $3.06 \pm 0.03$ folds.

\section{Discussion}

In the present study, the developmental period and longevity of the parasitoid on 3rd and 4th nymphal instars varied from 18.8 to 16.2 days and 8.3 to 8.8 days, respectively. The pre-ovipositional period on both nymphal instars was equal 1-2 days, whilst ovipositional period was longer (6.7, days; range, 5-8 days) on 4th instar than on 3rd instar (6.4 days; 4-7 days). These results suggest that the 4th instar was more suitable than the 3rd one for the growth and development of E. formosa. The present studies find support with the findings of
Grille et al. (2012) who observed that the developmental time of the Uruguayan parasitoid strain was 16.6 days when it parasitised the 4th instar of whitefly on tobacco plants. Similar to present findings, Donnell and Hunter (2002) reported developmental time faster and higher adult emergence rate in E. formosa on the 4th instar than on the 1st instar of whiteflies. Similarly the developmental period of E. formosa from egg to adult emergence attained 11.9 to 15 days at $27{ }^{\circ} \mathrm{C}$ on tomato (Stenseth 1971) and bean plants (Donnell and Hunter 2002). In host-parasite relation, the growth and development of parasitoid at the time of parasitisation was affected by the age of the host ( $\mathrm{Hu}$ and Vinson 2000). Similarly $\mathrm{He}$ et al. (2019) reported that age-stage life table analysis indicated that E. formosa developmental duration was shorter, fecundity was higher and longevity was greater on B. tabaci B than on Q. In the present findings, the longevity of female parasitoids was 8.8 days when parasitised 4th instar and 8.3 days on the 3rd instar. This is may be due to the adult parasitoid before parasitising the 4th instar nymphs had fed on the

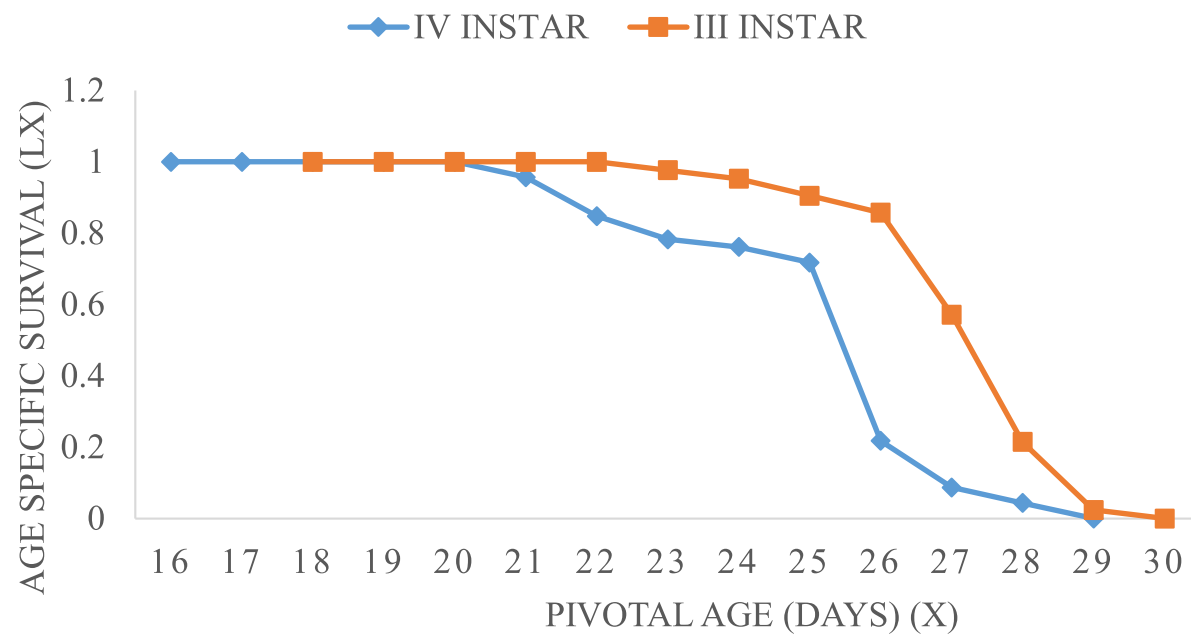

Fig. 1 Age-specific survival $\left(I_{x}\right)$ of E. formosa on third and fourth nymphal instars of $T$. vaporariorum 


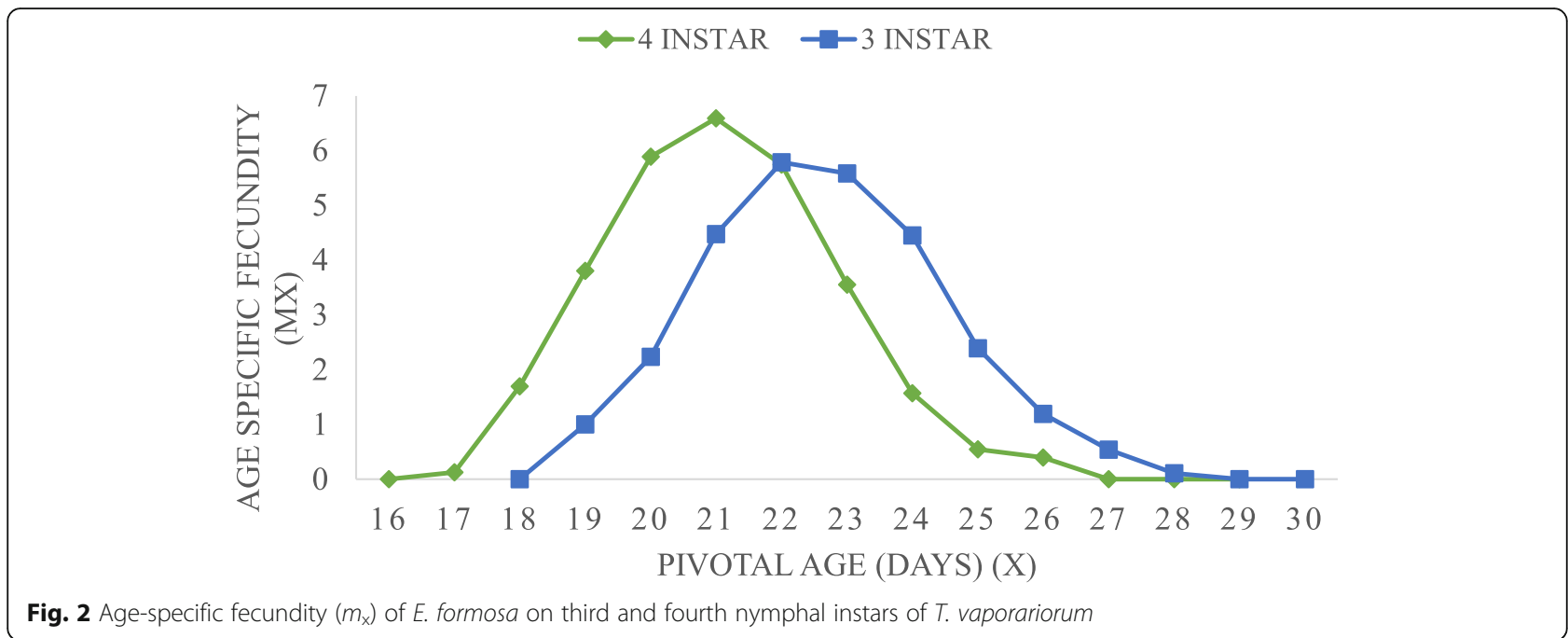

appropriate nymphal instar of whitefly. E. formosa females are synovigenic in nature and need hosts for feeding to mature their eggs; hence, it acts as a predator as well as through oosorption; it prolonged its longevity which resulted longer life of adult parasitoid (Van Keymeulen and Degheele 1997). In the present findings, net reproductive rate was 27.78 females/females in the case of 3rd instar and 29.93 in case of the 4th instar which was higher at elder nymphal instars. The weekly multiplication rate was $2.80 \pm 0.03$ days and $3.06 \pm 0.03$ folds on 3rd and 4th nymphal instars of whitefly, respectively. In the present study, the egg laying of parasitoid was reduced in the latter half of its lifetime. Also, it indicated that the 4th nymphal instars of the whitefly was the most suitable for the growth and development of $E$. formosa. Population growth rate is a more reliable indicator of a population's ability to exploit its environment by increasing in number, compared to individual life history traits. Construction of life tables and calculation of intrinsic rates of increase and some other demographic parameters were widely used for studying the effects of different factors on arthropod population growth. This approach has been used in several hosts (Gholamzadeh et al. 2012). The fecundity and longevity can be affected by the host on which the wasp was reared. E. formosa reared on a large whitefly such as Aleyroda prolotella had significantly more ovarioles than those reared on smaller hosts such as $T$. vaporariorumm (Szabo et al. 1993). Gamarra et al. (2020) reported that the maximum number of eggs and female offspring was produced at $20{ }^{\circ} \mathrm{C}$, but shifted towards $25{ }^{\circ} \mathrm{C}$ under fluctuating temperatures, with maximum population growth at around $24{ }^{\circ} \mathrm{C}$ with a finite rate of increase, $\lambda$, of 1.137 and a population doubling time of 5 days. The present study was almost similar to the study of Hoddle et al. (1998a) who reported that $E$. formosa reared on $T$. vaporariorum oviposit 5 eggs per day. Encarsia species has a low parasitism rate at emergence, which increases gradually to the maximum level, maintained for some time and then decreases during the last phase of adult life (Qiu et al. 2004).

Table 3 Population growth parameters of E. formosa parasitising fourth nymphal instars of T. vaporariorum

\begin{tabular}{|c|c|c|c|}
\hline \multirow{2}{*}{$\begin{array}{l}\text { S. } \\
\text { No. }\end{array}$} & \multirow[t]{2}{*}{ Parameter } & \multicolumn{2}{|l|}{ Estimate $\pm S E$} \\
\hline & & Third instar & Fourth instar \\
\hline 1. & Gross reproductive rate (GRR) (females/female) & $27.78 \pm 0.33$ & $29.93 \pm 0.43$ \\
\hline 2. & Net reproductive rate $\left(R_{0}\right)$ (females/female) & $26.71 \pm 0.56$ & $27.15 \pm 0.57$ \\
\hline 3. & Approximate generation time $\left(T_{c}\right)$ (days) & $22.53 \pm 0.26$ & $20.89 \pm 0.28$ \\
\hline 4. & Innate capacity for natural increase $\left(r_{c}\right)$ (females/female/day) & $0.1458 \pm 0.001$ & $0.1581 \pm 0.002$ \\
\hline 5. & True intrinsic rate of increase $\left(r_{\mathrm{m}}\right)$ (females/female/day) & $0.1472 \pm 0.001$ & $0.1596 \pm 0.002$ \\
\hline 6. & True generation time $(T)$ (days) & $22.32 \pm 0.25$ & $20.69 \pm 0.27$ \\
\hline 7. & Finite rate of natural increase $(\lambda)$ (females/day) & $1.16 \pm 0.002$ & $1.17 \pm 0.002$ \\
\hline 8. & Weekly multiplication rate (WM) (folds) & $2.80 \pm 0.03$ & $3.06 \pm 0.03$ \\
\hline 9. & Doubling time (DT) (days) & $4.71 \pm 0.04$ & $4.34 \pm 0.04$ \\
\hline
\end{tabular}




\section{Conclusion}

In the present study, relative preference, biology, population growth parameters and longevity of the parasitoid, E. formosa parasitising the greenhouse, T. vaporariorum were studied. All the demographic parameters of $E$. formosa were better on 4th nymphal instar of $T$. vaporariorum. Hence, the parasitoid can be utilised in the integrated pest management programme of the greenhouse whitefly.

\section{Acknowledgements}

The authors are thankful to the professor and Head, Department of Entomology for providing facilities to conduct the experiment. The authors are also thankful to the Indian Council of Agricultural Research, New Delhi, India, for funding the study.

\section{Authors' contributions}

AW conducted the experiments and collected the data. SCV designed the experiments and wrote the manuscript. PLS helped in designing the experiments and statistical analysis of data. NS and SP helped in writing and editing the manuscript. We confirm that the order of authors listed in the manuscript has been approved by all of us. Corresponding author is responsible for communicating with the other authors about progress, submissions of revisions and final approval of proofs. The authors read and approved the final manuscript.

\section{Funding}

Not applicable

Availability of data and materials

Not applicable

\section{Declarations}

Ethics approval and consent to participate

Compliance with ethical approval

\section{Consent for publication}

Not applicable

\section{Competing interests}

Not applicable

Received: 27 January 2021 Accepted: 26 April 2021

Published online: 06 May 2021

\section{References}

Birch LC (1948) The intrinsic rate of natural increase of an insect population. J Anim Ecol 17(1):15-26. https://doi.org/10.2307/1605

Boisclair J, Brueren GJ, van Lenteren JC (1990) Can Bemisia tabaci Gennadius be controlled with Encarsia formosa Gahan? WPRS Bulletin 13:32-35

Carey JR (1993) Applied demography for biologists with special emphasis on insects. Oxford University Press, New York, p 206

David BV (1971) Studies on South Indian Aleyrodidae. Rec Zool Surv India 70: $133-233$

Donnell DM, Hunter M (2002) Developmental rates of two congeneric parasitoids, Encarsia formosa and E. pergandiella (Hymenoptera: Aphelinidae), utilizing different egg provisioning strategies. J Insect Physiol 48(4):487-493. https://doi.org/10.1016/S0022-1910(02)00070-7

Gamarra H, Sporleder M, Carhuapoma P, Kroschel J, Kreuze J (2020) A temperature-dependent phenology model for the greenhouse whitefly Trialeurodes vaporariorum (Hemiptera: Aleyrodidae). Virus Res 289:198107. https://doi.org/10.1016/j.virusres.2020.198107

Gholamzadeh M, Ghadamyari M, Salehi L, Hoseininaveh V (2012) Effects of amitraz, buprofezin and propargite on some fitness parameters of the parasitoid Encarsia formosa (Hymenoptera: Aphelinidae), using life table and International Organization of Biological Control Methods. J Entomol Soc Iran 31:1-14
Grille G, Lorenzo ME, Burla JP, Franco J, Basso C (2012) Parasitoid niches of Encarsia formosa and Encarsia lycopersici (Hymenoptera: Aphelinidae) exploiting Trialeurodes vaporariorum (Hemiptera: Aleyrodidae). FLA Entomol 95(4):1024-1030. https://doi.org/10.1653/024.095.0431

He Y, Liu Y, Wang K, Zhang Y, Wu Q, Wang S (2019) Development and fitness of the parasitoid, Encarsia formosa (Hymenoptera: Aphelinidae), on the B and Q of the sweetpotato whitefly (Hemiptera: Aleyrodidae). J Econ Entomol 112(6): 2597-2603. https://doi.org/10.1093/jee/toz200

Hoddle MS, van Driesche RG, Sanderson JS (1998) Biology and use of the whitefly parasitoid Encarsia formosa. Annu Rev Entomol 43(1):645-669. https://doi.org/10.1146/annurev.ento.43.1.645

Howe RW (1953) The rapid determination of intrinsic rate of increase of an insect population. Ann Appl Bio 40(1):134-151. https://doi.org/10.1111/j.1744-7348.1 953.tb02372.x

Hu JS, Vinson SB (2000) Interaction between the larval endoparasitoid Campoletis sonorensis (Hymenoptera: Ichneumonidae) and its host the tobacco budworm (Lepidoptera: Noctuidae). Ann Entomol Soc Am 93: 220-224

Kos K, Tomanovic Z, Rojht H, Vidrih M, Trdan S (2009) First massive occurrence of greenhouse whitefly parasitoid, Encarsia formosa Gahan (Hymenoptera: Aphelinidae) on greenhouse whitefly, Trialeurodes vaporariorum Westwood (Homoptera: Aleyrodidae) in Slovenia. Acta Agric Slov 93:285-291

Palevsky E, Soroker V, Weintraub P, Mansour F, Abu Moach F, Gerson U (2001) How specific is the phoretic relationship between broad mite, Polyphagotarsonemus latus (Banks) (Acari: Tarsonemidae), and its insect vectors? Exp Appl Acarol 25(3):217-224. https://doi.org/10.1023/A:101064 5315630

Qiu YT, van Lenteren JC, Drost YC, Posthuma-Doodeman CJAM (2004) Life-history parameters of Encarsia formosa, Eretmocerus eremicus and Encarsia mundus, aphelinid parasitoids of Bemisia argentifolii (Hemiptera: Aleyrodidae). Eur J Entomol 101:83-94

Sheoran OP, Tonk DS, Kaushik LS, Hasija RC, Pannu RS (1998) Statistical software package for agricultural research workers. In: Hooda DS, Hasija RC (eds) Recent advances in information theory, statistics and computer applications. CCS HAU, Hisar, pp 139-143

Singh (2017) Population modeling and management of greenhouse whitefly in tomato under protected cultivation. Ph.D. Thesis. Department of Entomology, CSK Himachal Pradesh Krishi Vishvavidyalaya, Palampur. 340.

Singh V, Sood AK (2018) First record of Encarsia formosa Gahan, an aphelinid parasitoid of greenhouse whitefly from India and its dynamics on tomato grown under protected environment. J Bio Con 32(1):1-7. https://doi.org/1 $0.18311 / \mathrm{jbc} / 2018 / 16317$

Sood AK, David BV (2012) The greenhouse whitefly, Trialeurodes vaporariorum (Westwood). In: The whitefly or mealywing bugs (David BV (ed). LAP Lambert Academic Publishing Gmbh and Co. KG, Germany. 411.

Sood S, Sood AK (2002) Incidence and record of host plants of the greenhouse whitefly, Trialeurodes vaporariorum (Westwood) from Himachal Pradesh. Pest Manag Econ Zool 10:81-86

Soto A, Norero A, Apablaza J, Estay Y (2001) Requerimientos térmicos para el desarrollo de Encarsia formosa (Hymenoptera: Aphelinidae) criado en Trialeurodes vaporariorum (Hemiptera: Aleyrodidae). Ciencia e Invest Agra 28(2):103-106. https://doi.org/10.7764/rcia.v28i2.441

Stenseth C (1971) Effect of temperature on the development of Trialeurodes vaporariorum Westwood. Forsk Fuget Fors Landpruket 22:493-496

Szabo P, van Lenteren JC, Huisman PWT (1993) Development time, survival and fecundity of Encarsia formosa Gahan on Bemisia tabaci Gennadius and Trialeurodes vaporariorum. WPRS Bulletin 16:173-176

van Keymeulen K, Degheele D (1997) The development of oocytes and the lapse of time for adult emergence of Encarsia formosa Gahan 1924 at a constant temperature. Mededelingen van de Faculteit Landbouwwetenschappen. Rijksuniversiteit Gent 42:1279-1287

\section{Publisher's Note}

Springer Nature remains neutral with regard to jurisdictional claims in published maps and institutional affiliations. 